Article

\title{
Aggregation and Molecular Properties of $\beta$-Glucosidase Isoform II in Chayote (Sechium edule)
}

\author{
Alberto Cruz Rodríguez ${ }^{1}$, Fabiola Anaid Sánchez Esperanza ${ }^{1}$, Eduardo Pérez-Campos ${ }^{1}$, \\ María Teresa Hernández-Huerta ${ }^{2}$ (D), Laura Pérez-Campos Mayoral ${ }^{3}$, \\ Carlos Alberto Matias-Cervantes ${ }^{2}$, Alexis Martínez Barras ${ }^{4}$, Gabriel Mayoral-Andrade ${ }^{3}$, \\ Luis Ángel Santos Pineda ${ }^{1}$, Aymara Judith Díaz Barrita ${ }^{1}$, Edgar Zenteno ${ }^{5}$, Carlos Romero Díaz ${ }^{3}$, \\ Ruth Martínez Cruz ${ }^{3}$, Eduardo Pérez-Campos Mayoral ${ }^{3}$, Edith Alhelí Bernabé Pérez ${ }^{1}$, \\ Alma Dolores Pérez Santiago ${ }^{1}$ D , María del Socorro Pina-Canseco ${ }^{3, *}$ and \\ Margarito Martínez Cruz ${ }^{1, *}$ \\ 1 Tecnológico Nacional de México/IT de Oaxaca, Oaxaca 68030, México; cruz.bio90@gmail.com (A.C.R.); \\ plaqueta_hemostasia@yahoo.com.mx (F.A.S.E.); perezcampos@prodigy.net.mx (E.P.-C.); \\ santospineda07@gmail.com (L.Á.S.P.); aymara.diaz@gmail.com (A.J.D.B.); \\ edith.bp1106@gmail.com (E.A.B.P.); aperez_santiago@hotmail.com (A.D.P.S.) \\ 2 CONACyT Facultad de Medicina y Cirugía, Universidad Autónoma Benito Juárez de Oaxaca, Oaxaca 68020, \\ México; marte-hh28@hotmail.com (M.T.H.-H.); carloscervantes.ox@outlook.com (C.A.M.-C.) \\ 3 Centro de Investigación Facultad de Medicina UNAM-UABJO, Facultad de Medicina y Cirugía, \\ Universidad Autónoma “Benito Juárez” de Oaxaca, Oaxaca 68020, México; lperez.cat@uabjo.mx (L.P.-C.M.); \\ drmayoral@gmail.com (G.M.-A.); carlos.rom.74he@gmail.com (C.R.D.); rmc.azul@gmail.com (R.M.C.); \\ epcm@live.com.mx (E.P.-C.M.) \\ 4 Facultad de Ingeniería, Universidad Autónoma de Querétaro, Santiago de Querétaro 76017, México; \\ saxbarras@outlook.com \\ 5 Facultad de Medicina de la Universidad Nacional Autónoma de México, Ciudad de México 04510, México; \\ ezenteno@servidor.unam.mx \\ * Correspondence: socopina12@hotmail.com (M.d.S.P.-C.); martinezcu9@hotmail.com (M.M.C.); \\ Tel.: +52-951-221-1348 (M.d.S.P.-C.); +52-951-530-8625 or 52-9515161140 (M.M.C.)
}

Received: 9 March 2020; Accepted: 28 March 2020; Published: 8 April 2020

\begin{abstract}
The presence of isoforms of $\beta$-glucosidase has been reported in some grasses such as sorghum, rice and maize. This work aims to extract and characterize isoform II in $\beta$-glucosidase from S. edule. A crude extract was prepared without buffer solution and adjusted to $\mathrm{pH}$ 4.6. Contaminating proteins were precipitated at $4{ }^{\circ} \mathrm{C}$ for $24 \mathrm{~h}$. The supernatant was purified by chromatography on carboxymethyl cellulose (CMC) column, molecular exclusion on Sephacryl S-200HR, and exchange anionic on QFF column. Electrophoretic analyzes revealed a purified enzyme with aggregating molecular complex on SDS-PAGE, Native-PAGE, and AU-PAGE. Twelve peptides fragments were identified by nano liquid chromatography-tandem mass spectrometry (nano LC-ESI-MS/MS), which presented as $61 \%$ identical to Cucurbita moschata $\beta$-glucosidase and $55.74 \%$ identical to $\beta$-glucosidase from Cucumis sativus, another Cucurbitaceous member. The relative masses which contained 39\% hydrophobic amino acids ranged from 982.49 to 2,781.26. The enzyme showed a specificity to $\beta$-D-glucose with a $K_{m}$ of $4.59 \mathrm{mM}$, a $V_{\max }$ value of $104.3 \mu \mathrm{M} \cdot \mathrm{min}^{-1}$ and a $k_{\text {cat }}$ of $10,087 \mu \mathrm{M} \cdot \mathrm{min}^{-1}$ using $p$-nitrophenyl- $\beta$-D-glucopyranoside. The presence of molecular aggregates can be attributed to non-polar amino acids. This property is not mediated by a $\beta$-glucosidase aggregating factor (BGAF) as in grasses (maize and sorghum). The role of these aggregates is discussed.
\end{abstract}

Keywords: $\beta$-glucosidase; Sechium edule; aggregating protein; Cucurbitaceae 


\section{Introduction}

$\beta$-Glucosidases (E.C. 3.2.1.21) are enzymes that hydrolyze glycosidic bonds to release residues, non-reducing sugar terminal glycosides, oligosaccharides, and aglycones. The wide distribution of $\beta$-glucosidases in various organisms, both eukaryotes, and prokaryotes has been frequently mentioned. Their existence and high molecular preservation indicates the importance that of these molecules in the biological processes of various organisms, particularly in plants, in which a variety of functions have been reported. Among these processes participation in secondary metabolism, in the defense process [1], catabolism and lignification of the cell wall, symbiosis [2-6], biosynthesis and abscisic acid catabolism (ABA) [7,8], and antioxidant synthesis [9] are noted. Numerous cases of multiple enzyme isoforms have been demonstrated in plants such as sorghum, rice or maize. The function is attributed to several factors such as specificity towards one or a group of structurally related substrates, the site where it is synthesized in tissue or organelles, and the interaction with individual-specific substrates.

$\beta$-Glucosidase from Sechium edule [10] shows sililarities with the Cucurbitaceae family ones, particularly with those from Cucurbita moschata (squash) and Cucumis satious (cucumber) [11]. This is indicated by the found partial sequence of amino acids that is identical to one of its fragments, as well as its specificity to the substrate. However, other partial characterization data could not be compared with different glucosidases in the family because they are not reported. Considering the classification proposed by Henrissat $[12,13]$ which is based on the similarity between the sequence of amino acids and structure, as well as sequences of multiple-domain enzymes, we present data suggesting a clear reasoning as to why $\beta$-glucosidase in Sechium edule could be classified as belonging to the GH1 family. Due to a lack of information on this family, the contribution of new knowledge is considered important, as this novel enzyme could be considered for use in industrial applications in food production, energy, and pharmaceuticals, among others [14-16]. Its potential use depends on a more complete knowledge of its characteristics.

Previously, the purification and partial characterization of fraction I (isoform I) of $\beta$-glucosidase from chayote was performed [10]. The present study evaluates work isolation and purification, properties, and which could be classified in the GH1 family and aggregation characteristics of $\beta$-glucosidase isoform II. The juice of epicarp and mesocarp in chayote has a physiological $\mathrm{pH} 6.8$ with 4.2 times more protein and 2.6 times more specific activity than in the conditions used in the extraction of isoform I [10]. Likewise, the procedure to isolate and purify isoform II has been modified, its composition, partial sequence of amino acids, identity with other members of the Cucurbitaceae family, kinetics, and the presence of molecular aggregates are shown. Finally, the possible physiological meaning of their high molecular weight molecular aggregates is discussed.

\section{Results and Discussion}

\subsection{Preparation of Crude Extract from Sechium edule}

The crude extract was prepared without the addition of a buffer (modified technique of Espíndola et al.) to obtain a homogenate with a physiological $\mathrm{pH}$ of 6.8 , as in previous reports [17]. It contained 4.3 times more protein and 2.7 times more specific activity than under the extraction conditions previously reported, using sodium acetate buffer $200 \mathrm{mM} \mathrm{pH} \mathrm{5.0.} \mathrm{At} \mathrm{pH} \mathrm{6.8,} \mathrm{the} \mathrm{enzyme} \mathrm{presented}$ the best conditions for maximum activity. In the SDS-PAGE electrophoretic analysis the Sechium edule $\beta$-glucosidase showed a multi-band pattern, typical of a crude extract. $\beta$-Glucosidase is recognized as an enriched band in addition to other proteins (Figure 1A Line 1). 
A

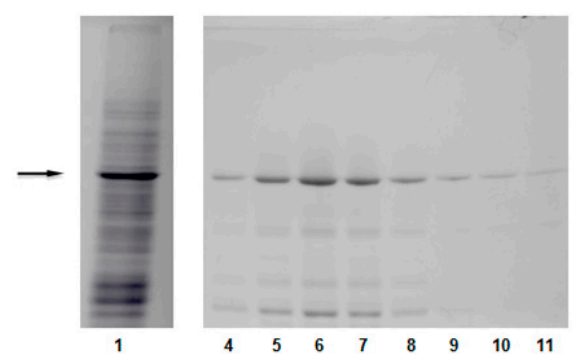

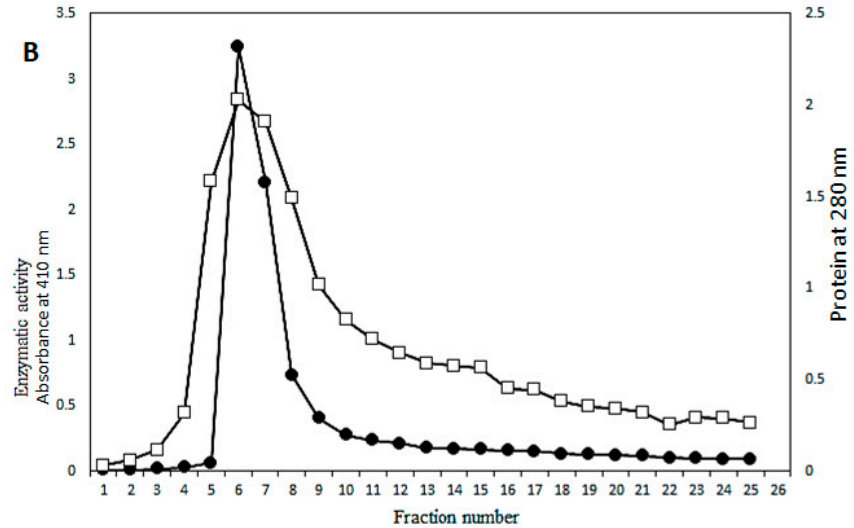

Figure 1. A. Fractions 4 to 11 with $2 \mathrm{~mL}$ of each, were analyzed in SDS-PAGE at $10 \%$ acrylamide, $4 \%$ bis-acrylamide. Lane 1 correspond to crude extract, the main band corresponds to $\beta$-glucosidase II, $(58 \mathrm{kDa})$ note that in none of the band's fractions molecular weight above the purified enzyme was observed. B. Chromatographic profile by cation exchange in CMC, column equilibrated with 200 mM sodium acetate buffer, the fractions were eluted with phosphate buffer $\mathrm{pH}$ 6.8. $\square-\square$ Protein, •-• Enzymatic activity.

\subsection{Extraction and Purification of $\beta$-Glucosidase II (Chayote Pulp Homogenate)}

In the crude extract, $1566 \mathrm{mg}$ of protein was obtained from $1 \mathrm{~kg}$ of Sechium edule pulp, which represents $0.16 \%$ of total protein, with $12,037 \mathrm{U}$ of $\beta$-glucosidase activity. The supernatant obtained after precipitation with glacial acetic acid contained $445.36 \mathrm{mg}$ of protein, corresponding to $28.59 \%$ of the protein from the initial extract with $10,479 \mathrm{U}$ of enzymatic activity (Table 1). This showed an $87 \%$ recovery in one simple step, and without further manipulation, it is important to note that the specific activity was amplified three times in the extract obtained.

Table 1. $\beta$-Glucosidase activity during the purification process of Sechium edule from $1 \mathrm{~kg}$ of pulp homogenate (chayote juice).

\begin{tabular}{cccccc}
\hline Fraction & $\begin{array}{c}\text { Total Protein } \\
(\mathbf{m g})\end{array}$ & $\begin{array}{c}\text { Activity of } \\
\boldsymbol{\beta} \text {-Glucosidase } \\
\mathbf{( U )}\end{array}$ & $\begin{array}{c}\text { Specific } \\
\text { Activity } \\
\mathbf{( U / m g )}\end{array}$ & $\begin{array}{c}\text { Purification } \\
\text { Factor }\end{array}$ & Yield (\%) \\
\hline Crude pulp extract & 1565.58 & $12,037.56$ & 7.69 & 1 & 100 \\
\hline $\begin{array}{c}\text { Glacial acetic acid } \\
\text { Protein supernatant }\end{array}$ & 445.36 & $10,479.30$ & 23.53 & 3.05 & 36.05 \\
\hline $\begin{array}{c}\text { Cationic } \\
\text { chromatography CMC }\end{array}$ & 19.25 & 4276.20 & 222.14 & 28.88 & 34 \\
\hline $\begin{array}{c}\text { Gel filtration } \\
\text { (S-200HR) }\end{array}$ & 5.107 & 4102.20 & 803.25 & 104.45 & 33.90 \\
\hline $\begin{array}{c}\text { Anionic } \\
\text { chromatography (QFF) }\end{array}$ & 4.855 & 4085.90 & 841.58 & 109.36 & 36 \\
\hline
\end{tabular}

\subsection{Purification of $\beta$-Glucosidase (Sechium edule) through Cation Exchange Chromatography}

Figure 1B shows the chromatographic profile of the eluted protein through of cation exchange chromatography, packed with $\mathrm{CMC}$, and eluded with phosphate buffer $\mathrm{pH}$ 6.8. From this fraction, $19.25 \mathrm{mg}$ of protein was obtained with 4,276.2 $\mathrm{U}$ of enzymatic activity, the specific activity was amplified 29 times (Table 1).

The analysis SDS-PAGE of this fraction shows a band with a molecular weight of $58 \mathrm{kDa}$ as was reported by Espíndola et al. [10]. It did not present protein components above the main band of $58 \mathrm{kDa}$, 
but we observed low molecular weight bands, in particular, those in lanes 5 to 8 , as shown in Figure 1B. This electrophoretic pattern is similar to that previously reported by the same authors.

At this stage of the purification process, the precipitate obtained by centrifugation with acid buffer $\mathrm{pH} 4.6$ was discarded. The supernatant was loaded into the cationic column and incubated $\left(\right.$ at $\left.-18^{\circ} \mathrm{C}\right)$ by $12 \mathrm{~h}$. The procedure was implemented to evaluate the degree of protection provided by the adsorption of the enzyme by CMC at this temperature. Considering the adhesion to the ion exchanger and the denaturation of proteins by freezing and thawing, it was observed that $\beta$-glucosidase adheres in such a way. When defrosted, it does not suffer denaturation, although other proteins with the same charge in the chayote extract were selectively excluded, obtaining more purified eluate fractions with phosphate buffer $\mathrm{pH}$ 6.8. The protection of the enzyme on CMC is, probably, due to the presence of non-polar amino acids, which were identified in the partial sequence of the amino acids analyzed (Table 2), forming hydrophobic interactions within the quaternary structure of the enzyme. This may allow exclusion of the surrounding water, forming "cages" and thus reinforcing the ion exchange, between charges of the hydrophilic amino acids of the $\beta$-glucosidase with the resin.

Table 2. Amino acid composition of the of $\beta$-glucosidase isoform II of Sechium edule.

\begin{tabular}{cccc}
\hline Amino Acids & & Res/mol & Residues/100\% \\
\hline Val & V & 4 & 2.23 \\
Phe & F & 12 & 6.70 \\
Gly & G & 14 & 7.82 \\
Ser & S & 7 & 3.91 \\
Ala & A & 16 & 8.94 \\
Tyr & Y & 17 & 9.49 \\
Gln & Q & 4 & 2.23 \\
Glu & E & 10 & 5.58 \\
Asp & D & 12 & 6.70 \\
Lys & K & 12 & 6.70 \\
Asn & N & 13 & 7.26 \\
Ile & I & 10 & 5.58 \\
Trp & W & 4 & 2.23 \\
Thr & T & 8 & 4.46 \\
His & H & 8 & 4.46 \\
Pro & P & 7 & 3.91 \\
Arg & R & 4 & 2.23 \\
Leu & L & 14 & 7.82 \\
Met & M & 3 & 1.67 \\
& & 179 & 100 \\
\hline
\end{tabular}

In Table 2, 179 amino acids identified in the enzyme $\beta$-glucosidase with $116 \mathrm{kDa}$ of molecular mass, this sequence corresponds to $35 \%$ of the total comparative sequence of $\beta$-glucosidase from Cucumis sativus (cucumber), containing 39\% of non-polar amino acids. The composition of the enzyme is rich in alanine, tyrosine, phenylalanine, asparagine, glycine, and leucine residues, but poor in tryptophan, methionine, and glutamine residues. In addition no cysteine was detected. Of the reported amino acids 39\% were non-polar and 61\% polar. According to the data obtained, it is implied that the protein contains at least one-third of non-polar amino acids, as these amino acids have a strong tendency to associate with each other inside the protein promoting hydrophobic interactions [18,19]. This suggests that the protein forms compact structures in some regions, which is a phenomenon described for other $\beta$-glucosidases for which we now have evidence as being in $\beta$-glucosidase II [20]. We think this property does not allow complete enzymatic digestion by trypsin [19], suggesting that it only hydrolyzes superficial peptides of the $\beta$-glucosidase II.

It is interesting to note that no cysteine was found, but there is likely to be some in the rest of the protein. Consequently, we assume that this amino acid is involved in the formation of disulfide bonds, which may participate in the dimerization of the protein. Hydrophobic interactions may be abundant and narrow, and this does not allow the exposure of disulfide bonds, reducing them by 2-mercaptoethanol (2-ME), and facilitating the disaggregation. 


\subsection{Purification of $\beta$-Glucosidase (Sechium edule) by Gel Filtration}

In the fraction purified by filtration gel, four peak maxima were identified. Enzymatic activity was identifiedin the second fraction (Figure 2A) determining a total of $5.1 \mathrm{mg}$ protein, with a specific activity of $803.25 \mathrm{U} / \mathrm{mg} / \mathrm{h}$, and an increase in purification factor of more than 100 times. Fraction 55, had higher protein concentration and higher enzymatic activity. This fraction together with fractions 56 and 57 were analyzed in dissociating electrophoresis (SDS-PAGE) at 10\%. At this stage a profile with fewer bands below the band of the $\beta$-glucosidase was observed, indicating the removal of contaminant components with a molecular weight of less than $58 \mathrm{kDa}$. This allowed us to obtain a more purified protein as seen in Figure 2B. It should be appreciated in SDS-PAGE analyses, that in both previous stages of purification components of higher molecular weight to purified $\beta$-glucosidase purified were not observed (Figures $1 \mathrm{~B}$ and $2 \mathrm{~B}$ ).
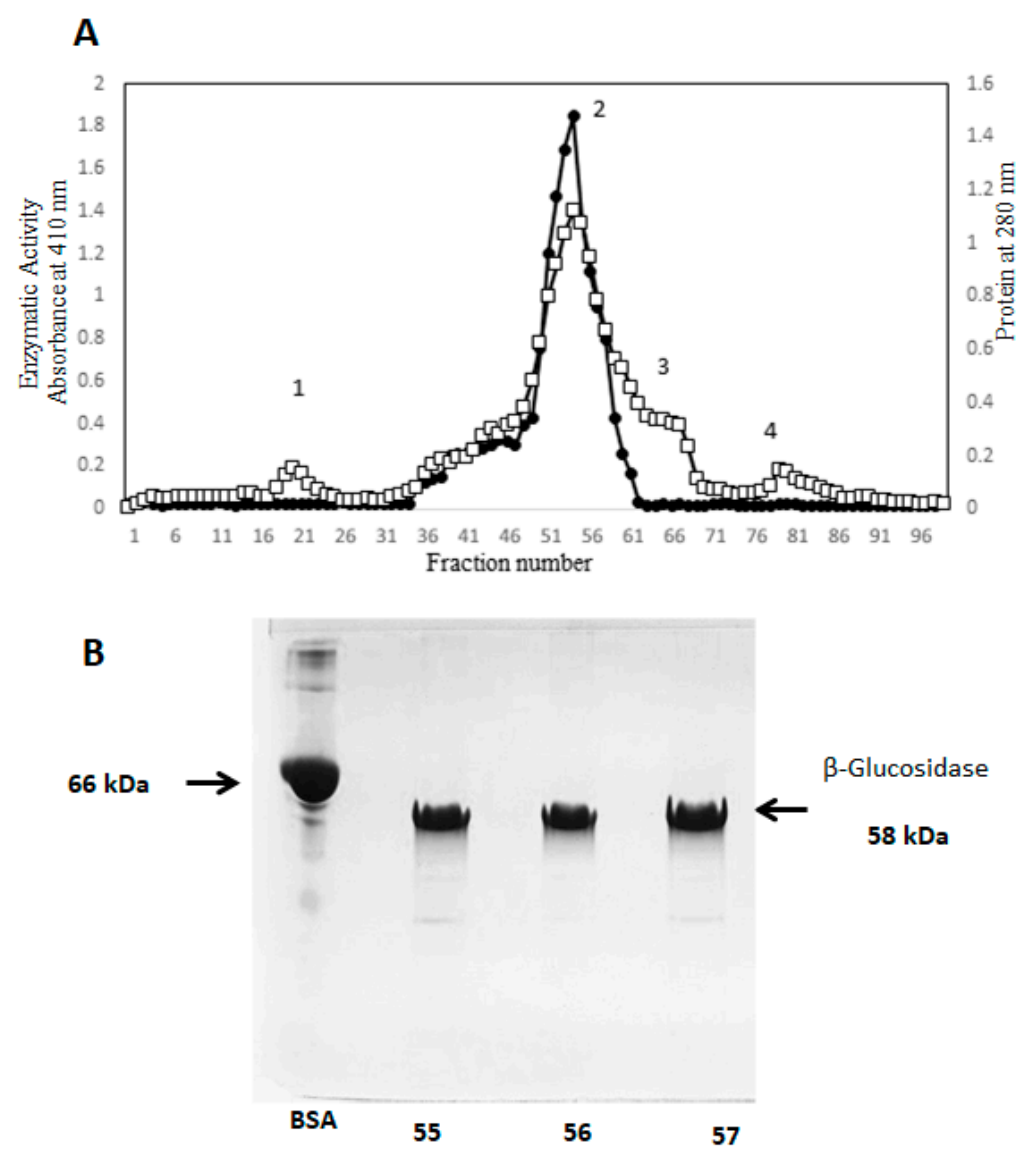

Figure 2. A. Purification chromatogram of $\beta$-glucosidase II by gel filtration, a column packed with Sephacryl S-200HR and equilibrated with phosphate buffer $\mathrm{pH}$ 7.2. $19 \mathrm{mg}$ of protein was loaded. The active fractions obtained from the cationic column were purified, the protein was eluted with a flow of $12 \mathrm{~mL} / \mathrm{h}$., in peak 2 the purified enzyme was obtained, $2 \mathrm{~mL}$ fractions were collected. B. SDS-PAGE analysis of fractions 55, 56 and 57, low molecular weight contaminants can be seen. $\square-\square$ Protein, $\bullet-\bullet$ Enzymatic activity.

\subsection{Purification of Sechium edule $\beta$-Glucosidase by Anion Exchange Chromatography and Detection of} Molecular Aggregates

Considering that the preparations obtained by gel filtration contain "contaminant" proteins of low molecular weight (Figure 2B), we implemented an additional step for the elimination of these through the anionic exchange. Enzymatic activity was identified in the first three fractions. These were eluted with PBS pH 7.2, presenting a total protein of $4.9 \mathrm{mg}$, which represents $0.31 \%$ of the total protein (Figure 3A, Table 1) and specific activity of $841.58 \mathrm{U} / \mathrm{mg} / \mathrm{h}$, with an increase of 109 times. SDS-PAGE 
analysis shows $\beta$-glucosidase purified preparation without contaminants of lower molecular weight. However, remarkably high molecular weight components appear (Figure 3B), which were not observed in the electrophoretic analysis of the preceding stages (Figures 1A and 2A), this finding suggests unmistakably high molecular weight protein remnants. These are considered molecular aggregates formed during anionic exchange chromatography.

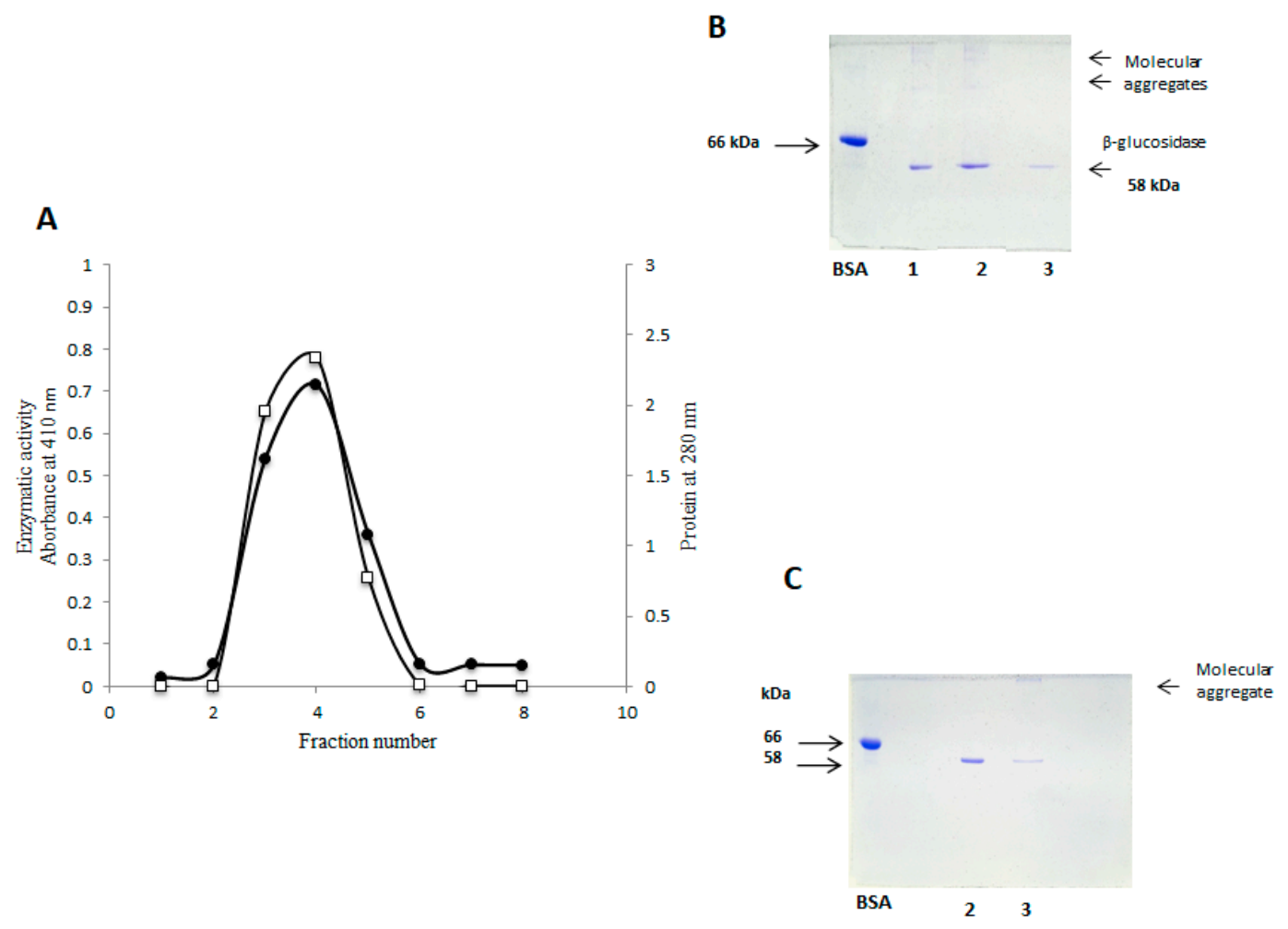

Figure 3. A. Chromatographic profile of purified $\beta$-glucosidase II by anion exchange, the QFF column $(5 \mathrm{~mL})$ was equilibrated with PBS 7.2. $5.1 \mathrm{mg}$ of protein was loaded, this was eluted at $30 \mathrm{~mL} / \mathrm{h}$, fractions were collected of $5 \mathrm{~mL}$. B. SDS-PAGE analysis of purified fractions 1, 2 and 3, where high molecular weight components are appreciated, which did not appear previously. C. SDS-PAGE of fraction 2 treated with $0.01 \%$ of 2-ME. (Line 2), fraction 2 without 2-ME (Line 3), a high molecular weight component (protein aggregates) is shown. $\square-\square$ Protein, $\bullet-\bullet$ Enzymatic activity.

These protein aggregates were dissolved in a PBS buffer at $\mathrm{pH}$ 6.8. 0.01\% of 2-ME was added, it was heated for $10 \mathrm{~min}$ to boil and centrifuged to 10,000 rpm for $10 \mathrm{~min}$, then SDS-PAGE was undergone. The electrophoretic analysis showed a pattern with a single band, corresponding to the $\beta$-glucosidase (Figure 3C, lane 2), the aggregate of high molecular weight is seen in lane 3, where the untreated sample was loaded.

\subsection{SDS-PAGE Electrophoresis}

The homogeneity, the molecular mass of the purified $\beta$-glucosidase, and the identification of high molecular weight aggregates were evaluated using SDS-PAGE. The molecular mass of $\beta$-glucosidase isoform II was defined as a single homogeneous band with a molecular weight of $58 \mathrm{kDa}$, similar to isoform I, as shown in Figure 4. It should be noted that the analyzed protein was purified and treated with $0.01 \%$ of $2-\mathrm{ME}$, prepared at the time of analysis. The electrophoretic pattern was significantly modified, when the purified and lyophilized protein was stored for a period of 1 to 6 months. It shows a complex electrophoretic pattern, as seen in the Figure 5A. This indicates the aggregation of this $\beta$-glucosidase. 


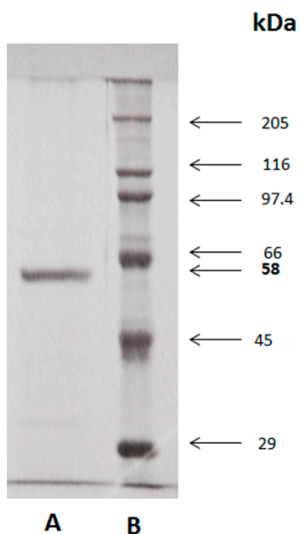

Figure 4. A. Molecular weight from purified $\beta$-glucosidase $(58 \mathrm{kDa})$ from epicarp and mesocarp of Sechium edule, under denaturing conditions (SDS-PAGE). In 10\% acrylamide gels, in the presence of SDS and 2-ME. B. Molecular weight standards: myosin (205 kDa), $\beta$-galactosidase (116 kDa), phosphorylase b (97.4 kDa), bovine serum albumin (BSA, $66 \mathrm{kDa})$, egg albumin $(45 \mathrm{kDa})$ and carbonic anhydrase (29 kDa).

A

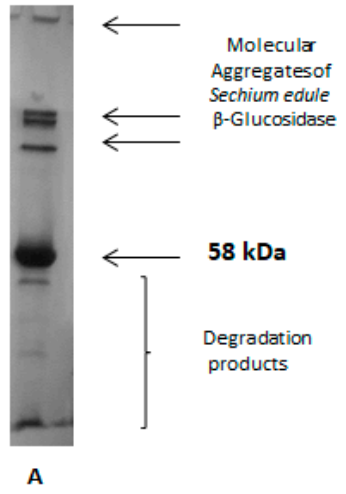

B

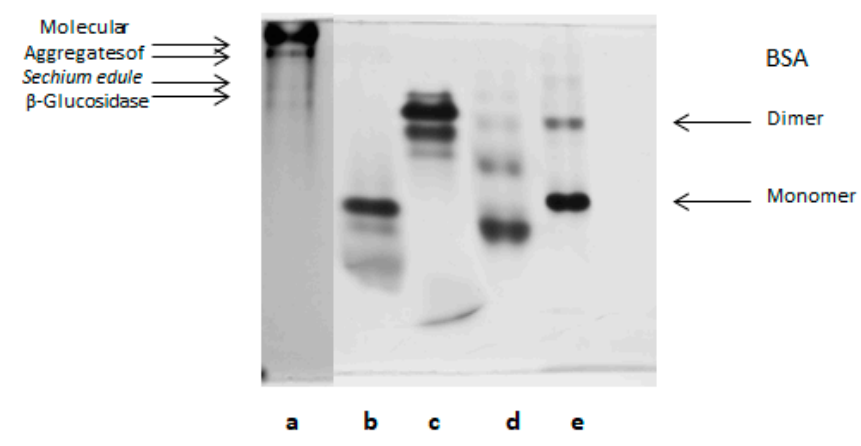

C
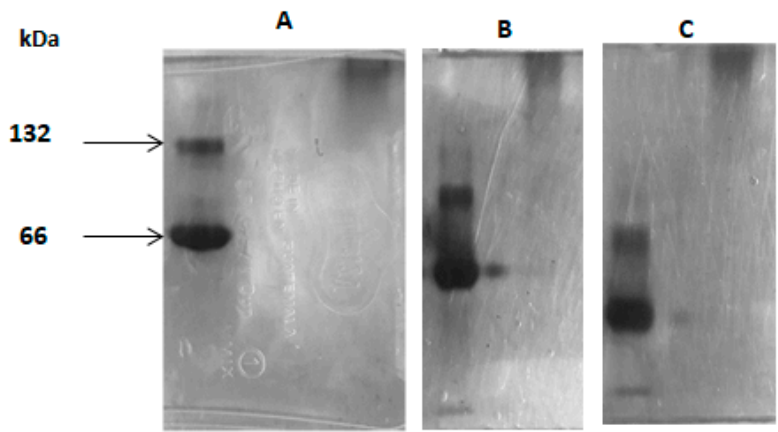

21

2

1

Figure 5. A. Electrophoretic analysis SDS-PAGE, note that this protein was purified and is the same sample as in Figure 3C. This protein has a marked tendency to form molecular aggregates. B. Electrophoretic analysis (PAGE-native) of purified $\beta$-glucosidase from Sechium edule after 3 weeks of storage, $10 \%$ polyacrylamide gel. Line a) $10 \mu \mathrm{g}$ of the enzyme $\beta$-glucosidase, molecular markers, Line b) $\alpha$-lactalbumin, c) carbonic anhydrase, d) egg albumin, e) BSA. C. Native-PAGE, of $\beta$-glucosidase II of Sechium edule in different concentrations of acrylamide: A) $7.5 \%$, B) $5.5 \%$ and C) $4.5 \%$, where 1) BSA electrophoretic mobility (monomer $66 \mathrm{kDa}$ and dimer $132 \mathrm{kDa}$ ) and 2) $\beta$-glucosidase II from Sechium edule. Note the zero mobility of $\beta$-glucosidase concerning acrylamide concentration. 


\subsection{Native-PAGE Electrophoresis}

To confirm the formation of molecular aggregates, native-PAGE electrophoresis was also additionally used, as described in the Experimental Section. The native PAGE analysis of this isoform II clearly presents the formation of molecular aggregates on the top of the molecular markers used. More specifically, when compared to BSA with a $66 \mathrm{kDa}$ monomer and a $132 \mathrm{kDa}$ dimer (Sigma-Aldrich technical bulletin) as shown in Figure 5. A component of high molecular weight and the presence of other proteins of lower weight inside of the gel, which is indicative of non-interaction with acrylamide and reinforces the hypothesis of aggregate formation (Figure 5B, line a). The aggregation phenomenon becomes more evident when a lyophilized 6 months-storage sample is dissolved in phosphate buffer $\mathrm{pH} 7.2$ and analyzed, no-defined bands pattern were observed, instead, a smeared sample was observed in the top of the separating gel, even opening the gel pore from 7.5 to $4.5 \%$ acrylamide concentration, which is evidenced by BSA protein used as a control, as shown in Figure 5C.

\subsection{Electrophoretic Analysis in Acetate-Urea pH 4.4}

Molecular aggregates of $\beta$-glucosidase were subjected to acid electrophoresis. In Figure 6 , line $B$, we observed two bands in the separating gel, which have less migration towards the anode than BSA (Figure 6, line A), as in the reference protein. This data describes $\beta$-glucosidase as a more acidic protein than BSA. The bands mentioned correspond to its native weight of $116 \mathrm{kDa}$ (dimer) and a band of $58 \mathrm{kDa}$ (monomer). We consider that the electrophoretic pattern of BSA in the same condition of analysis (Figure 6, line A) is similar to that observed in PAGE-native, in which charge isomers were identified. The pattern is similar to that reported in the BSA technical bulletin, already mentioned, and as shown in the Figure 5B, lane e. As in PAGE-native, $\beta$-glucosidase II was identified as a molecular aggregate and is not defined as a band (Figure 5B).

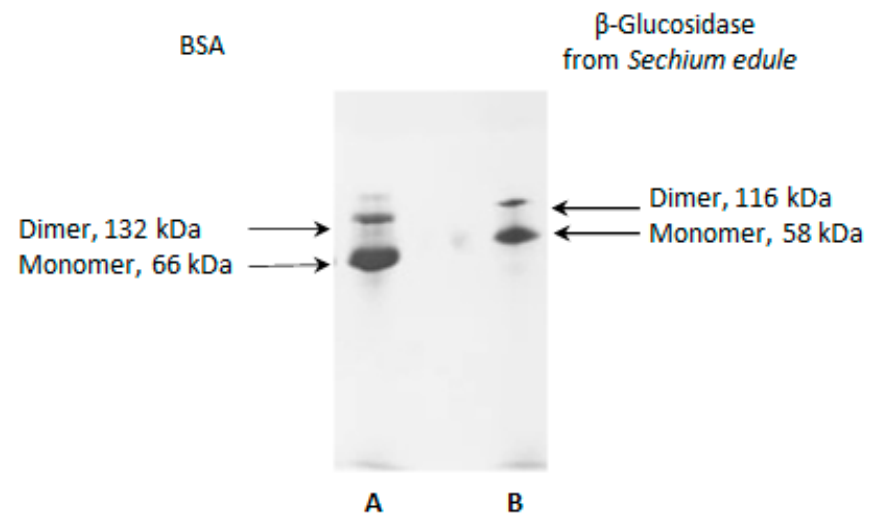

Figure 6. Electrophoretic analysis in Acetate-Urea (AU-PAGE) at $\mathrm{pH} 4.4$ in $10 \%$ acrylamide, where lane $\mathbf{A}$ is BSA and lane $\mathbf{B}$ correspond to $\beta$-glucosidase from Sechium edule. In this electrophoresis the protein migrates as a cation.

\subsection{Analysis in Two-Dimensional Electrophoresis}

The protein analyzed in 2D was appreciated as a spot, indicating a molecular mass of $58 \mathrm{kDa}$ with a $\mathrm{pI}$ range of 6.8 and corresponding to the isoform II of $\beta$-glucosidase (Figure 7). This allows us to confirm the data obtained by AU-PAGE and defines it as an isoform (II) because of not additional spots (proteins). 


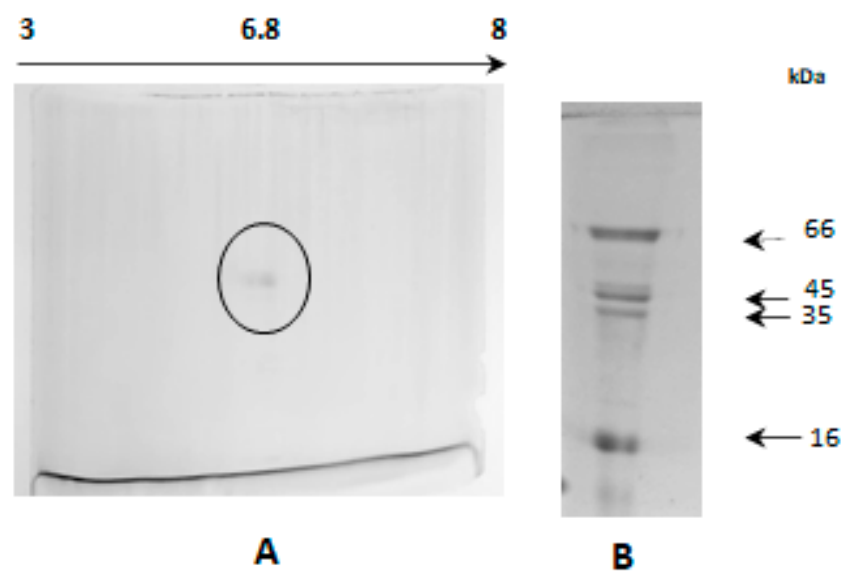

Figure 7. Two-dimensional (2D) electrophoresis of fresh, purified from $\beta$-glucosidase from Sechium edule II. Where: A. $6.8 \mathrm{pI}$ and B. Molecular weight markers: BSA (66 kDa), ovalbumin (45 kDa), pepsin (35 kDa) and trypsin inhibitor (16 kDa).

\subsection{Specificity Assays with Artificial Substrates and Kinetic Parameters}

The results obtained shown that specificity substrate for this enzyme was $\beta$-D-glucose $>$ $\beta$-D-galactose $>\beta$-D-fucose, using the general substrate $p$-nitrophenyl $(p$-NP) incorporated to these glucosides. This proves that $\beta$-glucosidase isoform II has a recognizable, non-specific feature (Table 3 ), presenting specificity in a narrow margin of related substrates of the same group. This result is similar to that described in other $\beta$-glucosidases [21].

Table 3. Substrates to determine the specificity of $\beta$-glucosidase isoform II from Sechium edule.

\begin{tabular}{c}
\hline Artificial Chromogenic Specific Substrates \\
\hline$p$-Nitrophenyl- $\beta$-D-glucopyranoside \\
$p$-Nitrophenyl- $\beta$-D-galactopyranoside \\
$p$-Nitrophenyl- $\beta$-D-fucopyranoside \\
\hline Non-Specific Substrates \\
\hline$p$-Nitrophenyl- $\beta$-D-manopyranoside \\
$p$-Nitrophenyl- $\beta$-D-lactopyranoside \\
$p$-Nitrophenyl- $\beta$-D-maltopyranoside \\
$p$-Nitrophenyl- $\alpha$-D-glucopyranoside \\
$p$-Nitrophenyl- $\beta$-D- $N$, $N^{\prime}$-diacetylcytotriose \\
$p$-Nitrophenyl- $\beta$-D-cellobioside \\
$p$-Nitrophenyl- $\beta$-D- $N$-acetylgalactosamine \\
\hline
\end{tabular}

$K_{m}$ was determined as a measure of the affinity of the enzyme for its substrate, therefore it depends on the type of substrate, among other variables, such as is reported for other $\beta$-glucosidases $[10,18]$. The kinetic parameters show slightly different values than those reported previously, with $p$-NP- $\beta$-D-glucopyranoside, $p$-NP- $\beta$-D-galactose and $p$-NP- $\beta$-D-fucopyranoside. In Table 4 , we present values of $K_{m}(\mathrm{mM}), V_{\max }\left(\mu \mathrm{M} \cdot \mathrm{min}^{-1} \cdot \mathrm{mg}^{-1}\right), k_{c a t}\left(\mathrm{~min}^{-1}\right)$, and the catalytic efficiencies for $\beta$-glucosidase II by $k_{\text {cat }} / K_{m}$ ratios (Figure 8). 
Table 4. Kinetic constant of $\beta$-glucosidase isoform II from Sechium edule.

\begin{tabular}{|c|c|c|c|c|c|}
\hline Substrate & $K_{m}(\mathrm{mM})$ & $\begin{array}{c}\text { Standard Error } \\
K_{m}\end{array}$ & $k_{\text {cat }}\left(\min ^{-1}\right)$ & $\begin{array}{c}\text { Standard Error } \\
k c a t\end{array}$ & $\begin{array}{l}10^{-3} \times k_{\mathrm{cat}} / K_{m} \\
\left(\mathrm{mM}^{-1} \mathrm{~min}^{-1}\right)\end{array}$ \\
\hline$p$ NPGlc & 4.59 & 0.49 & 10,086 & 1008 & 2197 \\
\hline$p$ NPGal & 5.72 & 0.45 & 13,718 & 1070 & 2398 \\
\hline$p$ NPFuc & 16.11 & 2.62 & 16,289 & 2638 & 1011 \\
\hline
\end{tabular}

A
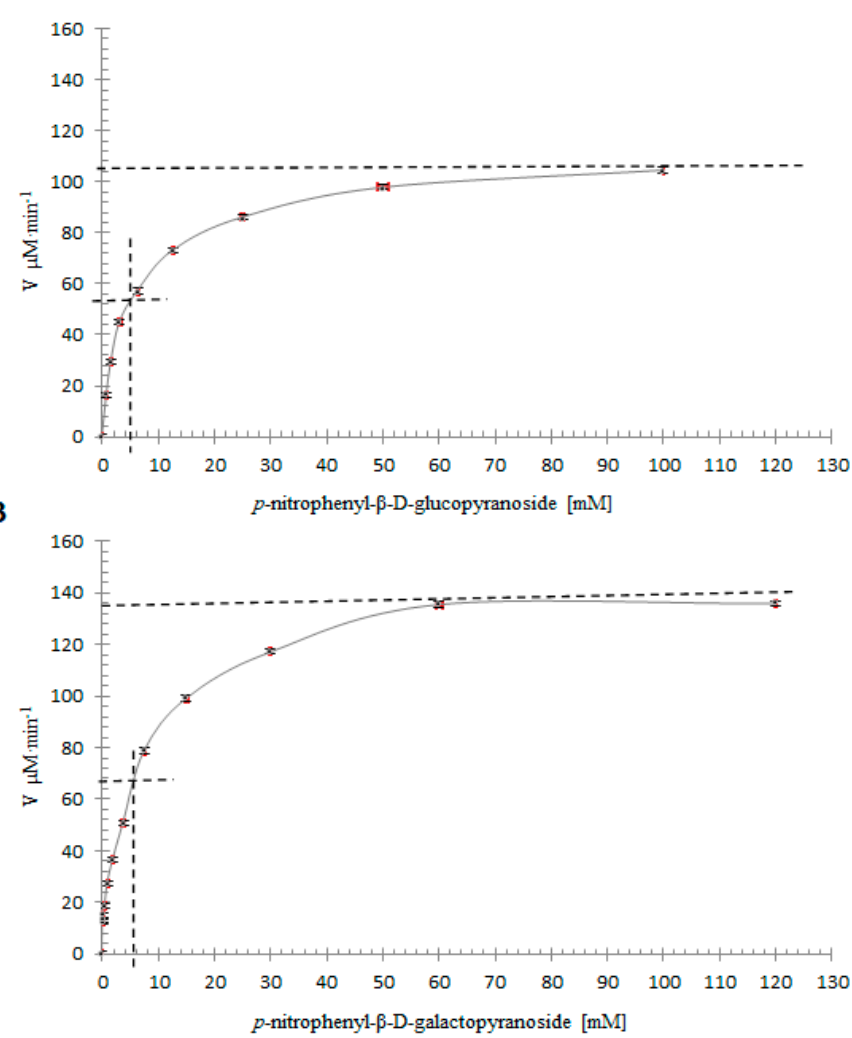

C

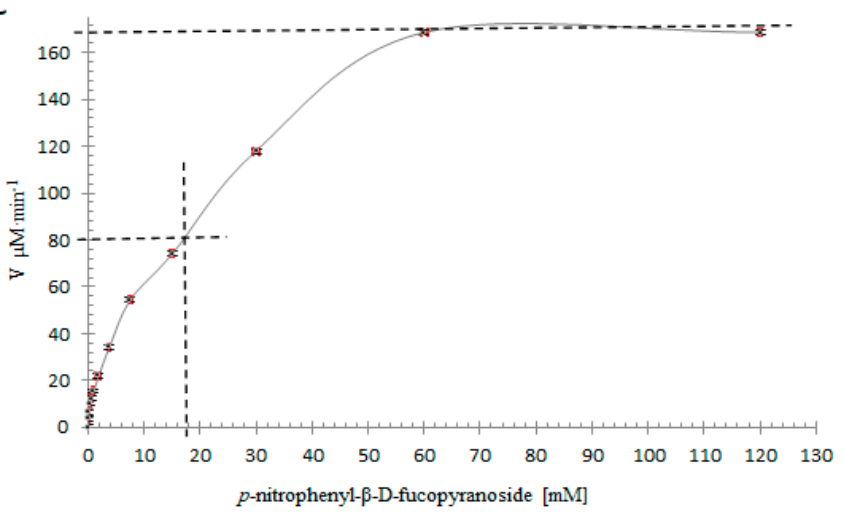

Figure 8. A. Enzymatic kinetics of $\beta$-glucosidase isoform II from Sechium edule. $4 \mu \mathrm{g}$ of the purified enzyme with different concentrations of $p$-nitrophenyl- $\beta$-D-glucopyranoside, obtained a $K_{m}$ of $4.6 \mathrm{mM}$ and $V_{\text {max }}=104.5 \mathrm{mM} \cdot \mathrm{min}^{-1}$. B. Enzymatic kinetics of $\beta$-glucosidase isoform II from Sechium edule, $4 \mu \mathrm{g}$ of the purified enzyme with different concentrations of $p$-nitrophenyl- $\beta$-D-galactopyranoside obtained a $K_{m}$ of $5.6 \mathrm{mM}$ and $V_{\max }=135 \mathrm{mM} \cdot \mathrm{min}^{-1}$. C. Enzymatic kinetics of $\beta$-glucosidase isoform II from Sechium edule, $4 \mathrm{mg}$ of the purified enzyme with different concentrations of $p$-nitrophenyl- $\beta$-D-fucopyranoside, a $K_{m}$ of $15.95 \mathrm{mM}$ was obtained and $V_{\max }=168.3 \mathrm{mM} \cdot \mathrm{min}^{-1}$. 
Activity was assayed using various concentrations of substrates, at $\mathrm{pH} 5.5$ and at $40{ }^{\circ} \mathrm{C}$, with $4 \mu \mathrm{g}$ of $\beta$-glucosidase. The release of $p \mathrm{NP}$ was measured, as described in the experimental methods. The kinetic constants were determined by analyzing the data nonlinear regression with Prism 6 (GraphPad Software. Inc., San Diego, CA, USA). All values are the averages of two separates experiments done in triplicate.

\subsection{Analysis of Tryptic Peptides}

While looking for sequence similarities with other proteins, several Cucurbitaceae $\beta$-glucosidases were identified, according to the Basic Local Alignment Search Tool (BLAST). It showed an identity of $60.89 \%$ and a value of 2e-59 in cyanogenic $\beta$-glucosidase-like (Cucurbita moschata) (XP 022960706.1); in cyano $\beta$-glucosidase-like (Cucurbita pepo subsp. Pepo) (XP 023516390.1) with 60.34\% identical and a value of 9e-59. It also predicted cyanogenic $\beta$-glucosidase-like (Cucumis melo)(XP 008450457.1) with $56.22 \%$, and 2e-57; and predicted a cyanogenic $\beta$-glucosidase-like (Cucumis sativus) (XP 011660112.1) with $55.74 \%$ identity and a value of $5 \mathrm{e}-57$. The identity of these sequences corresponds to the primary structure of these proteins. The $\beta$-glucosidase II showed high identity with four glucosidases of the Cucurbitaceae family, ranging from 56\% in Cucumis sativus to $61 \%$ in Cucurbita moschata.

The sequence obtained corresponds to $35 \%$ of both glucosidases (179 out of 511 amino acids). Additionally, the highest reported identity corresponds to Cucurbita moschata as mentioned above. The molecular mass obtained in Sechium edule is similar to Cucumis sativus and Cucurbita moschata, $58.142 \mathrm{kDa}$, with an identical number of amino acid residues (Table 5 and Figure 9).

Table 5. Analysis of tryptic peptides from the $58 \mathrm{kDa}$ subunit of $\beta$-glucosidase isoform II from Sechium edule (Sebg) by nano-LC-ESI-MS/MS.

\begin{tabular}{|c|c|c|c|c|c|}
\hline Name & Ion & $m / z^{1}$ & $\mathrm{MW}^{2}$ (Da) & Sequence & Start-End Sequence \% Identical \\
\hline Sebg2 & 903.42 & 3 & 2702.26 & NIWDTFTHKHPTR & $68-80-C m b g$ $62 \%$ y Csbg $54 \%$ \\
\hline Sebg4 & 408.89 & 3 & 1223.67 & YKEDVALMKK & 97-106-Cmbg 90\% y Csbg 80\% \\
\hline Sebg5 & 122.63 & 2 & 2439.26 & EYYNNLINELLANGIQP & 137-153-Cmbg $94 \%$ y Csbg $88.23 \%$ \\
\hline Sebg6 & 1391.63 & 2 & 2781.26 & HWITFNEPWSFSMGGYAQGANAPGR & 199-223-Cmbg 96\% y Csbg 88\% \\
\hline Sebg8 & 1164.07 & 2 & 2326.14 & NALDFLGLNYYTANYAK & 338-354-Cmbg 88\% y Csbg 76\% \\
\hline Sebg9 & 1333.14 & 2 & 2664.28 & IYITENGYLEIDGPPFHEMGIADK & 416-439-Cmbg 62.5\% y Csbg 62.5\% \\
\hline Sebg10 & 811.92 & 2 & 1621.84 & KV-YYHDHLYNLR & 440-451- Cmbg $66.6 \%$ y Csbg 50\% \\
\hline Sebg11 & 560.29 & 2 & 1118.58 & FGLTYIDYK & 483-491-Cmbg 100\% y Csbg100\% \\
\hline Sebg12 & 542.57 & 2 & 982.49 & WFENFLKT & $504-511-C m b g$ 100\% y Csbg $87.5 \%$ \\
\hline
\end{tabular}

In the terminal amino region, four homologous peptides were identified with Cucurbita moschata $\beta$-glucosidase. The VFGSASAAYQFEGAAFEDGK peptide from residue 46 to 65 with $100 \%$ identity, the NIWDTFTHKHPTR peptide from residue 68 to 80 with a $62 \%$ identity, the IYDHSDGDVALDQYHR peptide with $94 \%$ identity, from residue 81 to 96 , and the peptide YKEDVALMKK with 90\% identity, from residues from 97 to 106 (Table 5). With respect to residues 46 to 106, a continuous polypeptide of 59 amino acids was identified (Figure 9), which presents an identity of $79 \%$ with the tertiary structure of Oryza sativa (rice) in accordance with the I-TASSER server [22]. Also, when that there were no reports in databases of tertiary structures of $\beta$-glucosidases in Cucurbitacea, an Oryza sativa structure was used to identify the possible spatial location of the polypeptide obtained from Sechium edule. It was found that this sequence is on the surface (Figure 10), and suggests that peptides, obtained by digestion with trypsin, are located on the surface. Therefore, it is likely that the presence of non-polar amino acids (Table 2), are found inside the protein establishing strong hydrophobic interactions. Consequently, this forms molecular aggregates, which could have contributed to obtain a greater number of sequenced peptides. 


\title{
Multiple alignment
}

\author{
Sechium edule \\ Cucumis_sativus \\ Cucumis melo \\ Cucurbita_moschata \\ Cucurbita-pepo \\ oriza_sativa \\ Sechium edule \\ Cucumis sativus \\ Cucumis melo \\ Cucurbit̄a moschata \\ Cucurbita_pepo \\ oriza sativa \\ Sechium edule \\ Cucumis sativus \\ Cucumis melo \\ Cucurbit̄a_moschata \\ Cucurbita pepo \\ oriza_sativa \\ Sechium edule \\ Cucumis sativus \\ Cucumis melo \\ Cucurbita moschata \\ Cucurbita_pepo \\ oriza_sativa \\ Sechium_edule \\ Cucumis sativus \\ Cucumis melo \\ Cucurbit̄a_moschata \\ Cucurbita pepo \\ oriza_sativa \\ Sechium edule \\ Cucumis sativus \\ Cucumis melo \\ Cucurbit̄a_moschata \\ Cucurbita pepo \\ Oriza sativa \\ Sechium_edule \\ Cucumis sativus \\ Cucumis melo \\ Cucurbit̄a moschata \\ Cucurbita pepo \\ oriza sativa \\ Sechium edule \\ Cucumis_sativus \\ Cucumis melo \\ Cucurbita moschata \\ Cucurbita pepo \\ Oriza_sativa \\ Sechium edule \\ Cucumis sativus \\ Cucumis melo \\ Cucurbita moschata \\ Cucurbita_pepo \\ oriza_sativa
}

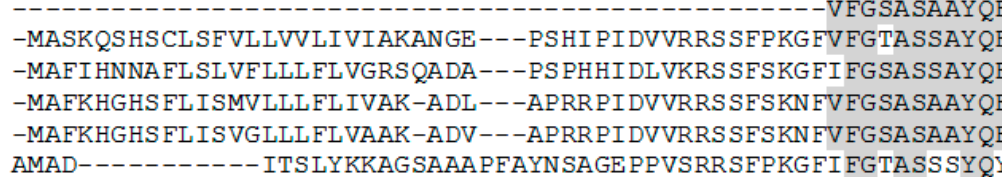

EGAAFEDGK-NIWDT FTHKH PTRI YDHS DGDVALDQYHRYKEDVALMKKM---------EGGAFEDGKRP SI WDNYT HQHPEKIYDHSNGDVAVNQYHRYKEDVALMKKMG FDAYRFSI EGAAQEDGKGP SI WDTYT HQHPEKIYDHSNGDIAI DQYHRYKEDIA ILKKMG FNAYRF SM EGAAFED GKGP SI WDNFT HQHPEKIY DHSN GDVALDQYHRYKEDVA ILKKMG FNAYRFSI EGAAFEDSKGP SI WDNFT HQHPEK IY DH SN GDVALDQYHRYKEDVA ILKKMG FNAYRF SI EGGAAEGGRGP SIWDTFT HQHPEKIADRSNGDVASDSYHLYKE DVRLMKDMGMDAYRF SI EYYNNL INELLANGIQP -

AWSRVLPKGKLSR GVNKKGI OYYNNL INEL LAKGIOPYVTL FHWDT POALEDEYGG FLG AWSRI LPKGKLSGGVNKKGIEYYNKL INELLANGI OPYVTL FHWDT PQALEDEYGGFRGP AWSRVLPKGKLSGGVNKK GI EYYNNL INELLRNGI QP FVTL FHWDT PQALEDEYGG FLGR AWSRVLPKGKLSGGVNKKGIEYYNNL INELLRNGI QP FVTL FHWDT PQALEDEYGGFLGR SWTRI LPNGSLRGGVNKE GI KYYNNL INELLSKGVQP FI TL FHWDS PQALEDKYNG FLSP

$$
\text { -KHW I TFNEP WSF SMGGYAQGANAPGR- }
$$

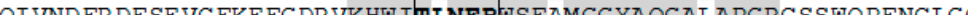
QIVND FRDYVDLC FKEFGDRVKHW ITLNEPWSF SMGGYAQGANAPGRCSSWQPYNCSGGD QIVNDYRDYAELC FKEFGDRVKHW ITLNEPWSF SMGGYAQGANAPGRCSSWQPYKCLGGD QIVNDYRDYAELC FKEFGDRVKHW ITLNEPWSF SMGGYAQGANAPGRCSSWQPYKCLGGD NI IND FKDYAE IC FKEFGDRVKNW IT FNEPNTFCSNGYATGLFAPGRCSPWEKGNCSVGD

SGTEPYIVGHNOTIAHAAAVKVYKTKYQAHOKGVTGITI VSTWYTPYSNSFADKKAANRS SGTEPYIVGHYOLLAHAAAVKVYKTKYOAHOKGLIGITLVTVWYAPYSNSEEDKRAAIRA SGTEPYIVGHYQLLAHAAAVKVYKTKYQAHQKGLI GITLVTVWYAPYSNSEEDKRAAIRA SGTEPYIVGHHQLLAHAAAVKVYKTKYQAYQKGVIGITLVTVWYTPNSNSEADKKAAIRA SGREPYTACHH QLLAHAE TVRL YKAKYQALQKGKI GI TLVS HW FVP FSRS KS NNDAAKRA

$$
\text { SLPKFSA }
$$

KNALDFLGLNYYTANYAK--

LDFALGW FLHPLTYGDYP PIMRELVKERLPKFTRAEAAL IKGSMDF LGLNYYTTNYAKDN LD FILGWYMHP ITYGDYP PVMRGLVKERLPKFS PEESAS LKGS IDF LGLNYYTANYAKDN LDFALGWYLHP ITYGDYP PIMRELVKERLPKFSAAESAS IKGS LDF LGLNYYTANYAKDN LD FALGWYLHP ITYGDYP PIMRELVKERLP KFSAAESAS IKGS LDF LGLNYYTANYAKDN ID FMFGW FMDPLIRGDYPLSMRGLVGNRLPQFTKEQSKLVKGA FDF IGLNYYTANYADNI

P POPYTDYRADLST DRNGVS IG PKFNATSWLAVYPKG FKDLLIHTKTKYKNPII 416 PNAPG PQPSYLTDYRADLST DRNGVS IGPKFSE ISWLAVYPEGLKS LLVYTKTKYKDPVI 416 PNAPGPQPSYLTDYRADLSTDRNGVS IGPKFSEVSWLAVYPQGLKELLIYTKTKYNDPFI 415 PNAPGQQPSYLTDYRADLSTDRNGVS IG PKFSEVSWLAVYPQGLKELLIYTKTKYNDPLI 415 PPSNGLNNSYT TDSRANLTGVRNG IP IG PQA-ASPWLYVYPQG FRDLLLYVKENYGNPTV 408

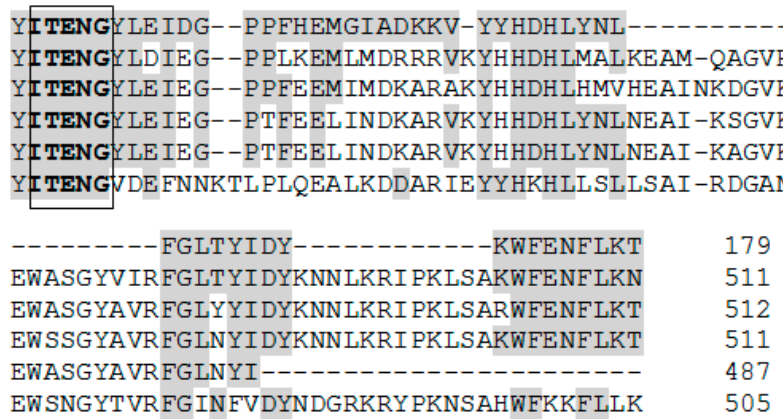

Figure 9. Partial sequence identity deduced by $\beta$-glucosidase isoform II from Sechium edule, Cucumis sativa, Cucurbita moschata, Cucurbita pepo, Cucumis melo. The multiple sequences were aligned using BLAST, in this figure the regions of identity with other reported $\beta$-glucosidases of some members of the Cucurbitaceae and Oriza sativa (Gramineae) families are indicated. There are also two motif peptides (in the boxes) showing those involved in the recognition of highly conserved sugar and the catalytic site in the GH1 family. 


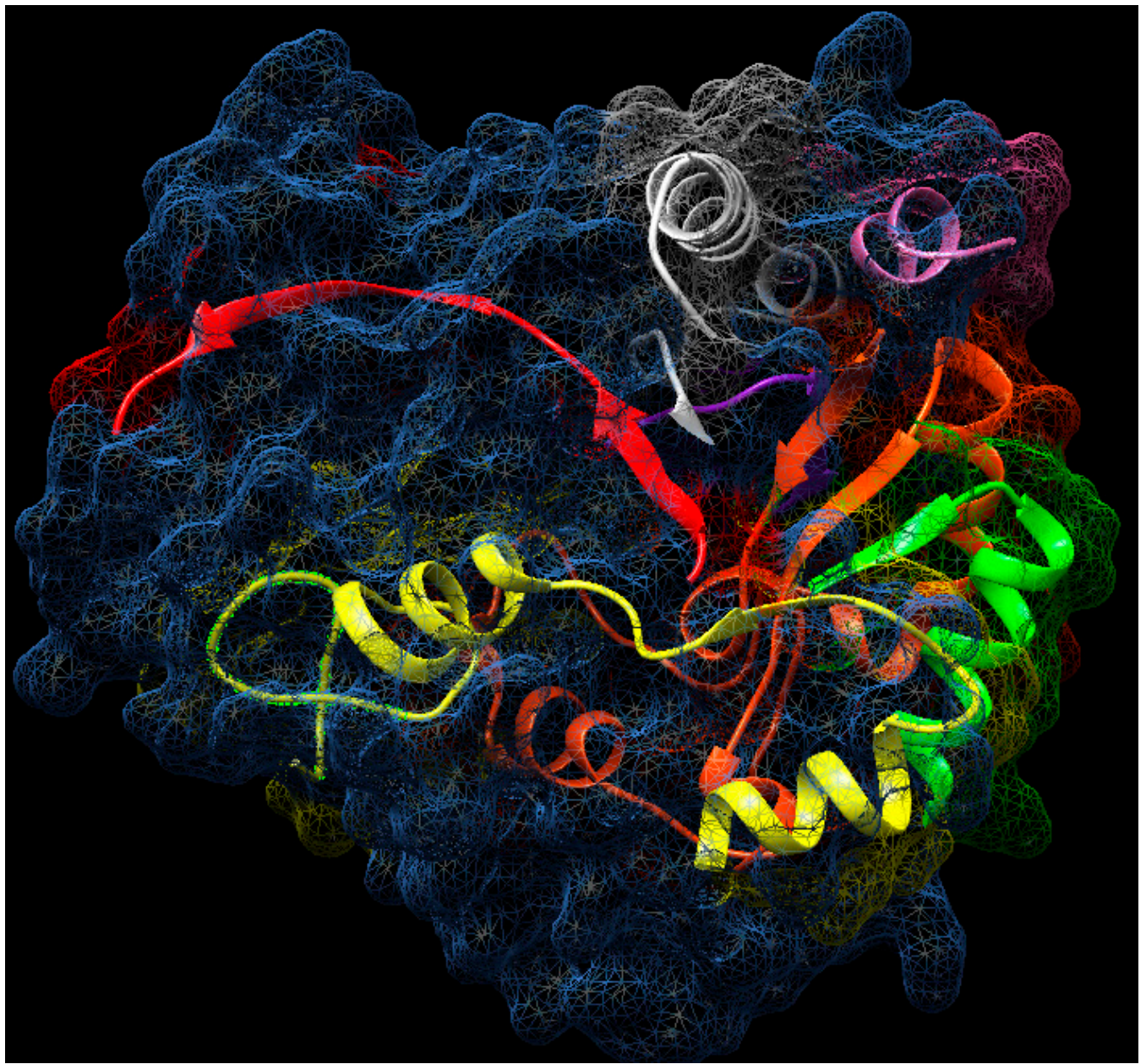

Figure 10. Location of $\beta$-glucosidase isoform II from Sechium edule amino acids residues (in cartoon colors) using the tertiary structure of $\beta$-glucosidase from rice as a template (surface representation in dots and spirals). $70 \%$ of the sequenced residues of $\beta$-glucosidase from Sechium edule are found on the surface of the protein, except residues 173 to 196 (yellow), residues 316 to 329 (red), and residues 456 to 462 (purple). 3PTM.pdb modified, using Chimera [23].

Other homologous sequences located in the middle region of the protein were: the EYYNNLINELLANGIQP peptide from residue 137 to 153 that showed 94\% identity; the HWITFNEPWSFSMGGYAQGANAPGR peptide from residue 199 to 223 with $96 \%$ identity (Table 5), which contains a conserved region (highlighted in the reframe) (Figure 9) that participates in the recognition of sugar, and is located in the catalytic site. This is conserved in families of $\beta$-glucosidases and classified into glycosyl hydrolases 1 (GH1) family. This motif peptide, in some members of the reported Cucurbitaceae family, presents the replacement of phenylalanine $(\mathrm{F})$ by leucine $(\mathrm{L})$ residues (Figure 9). It could be like that the recognition of the catalytic site is similar because of the since this substitution is exchanged by an amino acid of the same group. The sequence identified in $\beta$-glucosidase II is similar to that reported in several grasses [24-27], such as maize, sorghum, oat, and rice. Other peptides in the middle portion of the sequence, were SLPKFSAK, from residue 324 to 332 with 75\% identity, NALDFLGLNYYTANYAK from residue 338-354 with 88\% identity, and the IYITENGYLEIDGPPFHEMGIADK sequence of residue from 416-439 with $62.5 \%$ identity. These sequences were identical to $\beta$-glucosidase from Cucurbita moschata. In this last peptide, a second motif sequence (highlighted in the reframe) was found identical to those found in other Cucurbitaceae (Figure 9), and grasses [22,24-27]. These sequences are highly conserved, therefore, the 
similar three-dimensional structure of the eight-stranded $\beta / \alpha$ barrel (TIM-barrel) is possible, allowing classification with $\beta$-glucosidase II in the GH1 family [21]

At the end of the carboxyl-terminal sequences, another 3 peptide sequences were identified: KVYYHDHLYNLR from residue 440-451 with 67\% identity, FGLTYIDYK from residue 483 to 491 with $100 \%$ identity, and WFENFLKT from residue 504-511, also with $100 \%$ identity. We obtained $35 \%$ of the total sequence concerning Cucurbita moschata and Cucumis sativus. These data contain a similar number of amino acids and molecular masses to $\beta$-glucosidase II in Sechium edule (Table 5). It should be remembered that the highest peptide similarity was $61 \%$ identity with Cucurbita moschata.

\subsection{Molecular Aggregates}

We can conclude that the components of high molecular weight are the molecular aggregates identified in isoform II, and not those present in isoform I. In the electrophoretic analysis of purified fractions by cation exchange and gel filtration (Figure 2A), no molecular weight compounds greater than $\beta$-glucosidase and BSA were observed. These compounds were found in fractions obtained by anionic exchange. The aggregate was dissolved in $50 \mathrm{mM}$ citrate buffer $\mathrm{pH} 6.8$ with $0.01 \%$ of 2-ME. In line 2 , Figure $3 \mathrm{C}$, the absence of molecular aggregates of the $\beta$-glucosidase after the above-mentioned treatment, is observed. This is corroborated in line 3 by their presence in the same sample under standard conditions of SDS-PAGE in view of the high molecular weight component, at the top of the separating gel. This property is common in members GH1 family of $\beta$-glucosidase, particularly, in isoforms such as $\beta$-glucosidases from Zea mays (ZmGlu1) and Sinapis alba (MA1 myrosinase), which are also involved in the defense of plants in vivo [19].

One of the factors that could contribute to the formation of molecular aggregates is the presence of non-polar amino acids, in which case, $\beta$-glucosidase II has a proportion of $30 \%$, with respect to the sequence obtained (Table 2). An example of molecular aggregates is found in maize with $\beta$-glucosidase aggregating factor (BGAF) [28,29], which also presents polyspecific lectin activity, although in was not identified in preparations of crude extracts and purified fractions of Sechium edule, previously described in exudates of the fruit [30]. Recent studies suggest that the BGAF does not protect $\beta$-glucosidase in the case of maize. Further studies are needed [19].

The physicochemical properties described in $\beta$-glucosidase II, which could contribute to their stability are not completely understood, however, the common structural characteristics reported suggest that they are responsible for their stableness. This condition allows $\beta$-glucosidase to operate under special conditions, as the intestinal tract in certain insects. Vassão et al. describes the digestion resistance of three $\beta$-glucosidases in Zea mays and BGAF associated with this enzyme, myrosinase from Sinapis alba, and the $\beta$-glucosidase from Prunus dulcis (almonds). These proteins showed high resistance to the proteolytic enzymes from predator intestine (Spodoptera littoralis), maintaining the ability to catalyze the hydrolysis of glucosides [19]. However, there is no consensus on the belief that protein aggregates confer protection on the $\beta$-glucosidase. This needs for further study.

There is a lack of information about the formation of these aggregates in the $\beta$-glucosidase II in from Sechium edule. In fact, it is a little-known property. In this work, we report on the presence of non-polar amino acids (Table 2) which could participate in the formation of hydrophobic interactions, and point to $\beta$-glucosidase II as a pore-forming protein of molecular aggregates. This is possible due to the participation of at least one disulfide bond that would contributes to reinforcing this phenomenon, although the presence of cysteines was not identified. To support this hypothesis, the sequences obtained from BLAST (Figure 9) by multiple alignments with several $\beta$-glucosidases of the Cucurbitaceae and Gramineae families were compared, and the existence of four cysteines was identified. The presence of at least one disulfide bond, in the sequence of $\beta$-glucosidase II, may be involved in the dimerization of this enzyme, by understanding native molecular mass of $116 \mathrm{kDa}$, and monomers of $56 \mathrm{kDa}$. Its treatment with 2-ME disaggregated the protein, as shown in SDS-PAGE (Figure 3C) contributing to the reduction of disulfide bonds. 
The aggregation phenomenon in these Cucurbitaceae spp. is attributed to the intrinsic nature of this protein and, therefore, to the presence of hydrophobic amino acids in the tertiary structure. The biological significance of the formation or existence of molecular aggregates may be related to an evolutionary plant strategy to protect them from the degradation of the phytophagous insect by endogenous enzymes. It is accepted that one of the main functions of $\beta$-glucosidases is their participation in chemical defense against predatory insects, by continuously releasing toxic aglycones [19].

It is understood that the presence of non-polar amino acids is strongly associated with aggregates in the folded protein or core of proteins. As the molecules gather they have to form aggregates in aqueous solutions, regard water entropy, which increase when water molecules are released during protein folding in large aggregate formation. In $\beta$-glucosidase II, we should consider that its water content is $90 \%$, therefore, the protein is in the ideal medium for the formation of the active aggregates.

However, it is not clear whether the molecular aggregation of this class of protein has a protective effect against degradation by proteolytic enzymes. We suggest that due to its hydrophobic nature (similar to $\beta$-glucosidase 1 from maize, myrosinase, and almond), it does play an important role in protection. However, more studies should be carried out in this direction.

The study of this property will help us to understand the physiological role of molecular aggregates and will be of great interest (given the limited data) in other plants because of its high economic value, such as in the cultivation of Sechium edule, where some groups of bed bugs of the suborder Hemiptera [31] have been identified. At present, it is difficult to establish the role of these insects, however, some may potentially to become a pest for crops and the production of Sechium edule. Therefore, it is important to pursue the study of $\beta$-glucosidase and the possible role of molecular aggregates could have in the protecting this protein and its possible participation in the defense mechanisms in Cucurbitaceae species.

\section{Experimental}

\subsection{Preparation of the Modified Crude Extract of Sechium Edule}

To obtain $\beta$-glucosidase II, the method reported by Espíndola et al. [10] was used with the modifications described below. Chayote (Sechium edule) was washed and peeled. One kg of pulp (epicarp and mesocarp) was weighed and macerated without adding any buffer. The crude extract was filtered and centrifuged at $10,000 \mathrm{rpm}$ for $60 \mathrm{~min}$ at $4{ }^{\circ} \mathrm{C}$. The supernatant was adjusted to $\mathrm{pH} 4.6$ with glacial acetic acid and incubated at $4{ }^{\circ} \mathrm{C}$ for $24 \mathrm{~h}$. The precipitated was discarded and the supernatant was quantified [32] using BSA as standard and $p$ NPG as an enzymatic activity control [33].

\subsection{Enzyme Purification}

\subsubsection{Cation Exchange Chromatography}

Protein (445.36 mg) displaying 10,479 U of enzymatic activity, was loaded into a cation exchange column (20 cm in length $\times 1 \mathrm{~cm}$ in diameter) packed with CMC. Prior to this, it was equilibrated with sodium acetate (NaAc) buffer $200 \mathrm{mM} \mathrm{pH} 5.0$ to obtain at $\leq 0.01$ to $280 \mathrm{~nm}$ optical density, at room temperature $\left(25^{\circ} \mathrm{C} \pm 0.5\right)$. Once the sample was loaded, the column was incubated at $-18^{\circ} \mathrm{C}$ for $18 \mathrm{~h}$. After this period, the column was washed with the same buffer at room temperature. The enzyme was eluted with $200 \mathrm{mM}$ phosphate buffer $\mathrm{pH} 6.8$ with a flow of $35 \mathrm{~mL} / \mathrm{h}$. Fractions of $2.0 \mathrm{~mL}$ were collected, protein and enzymatic activities were quantified as described above.

\subsubsection{Molecular Exclusion Chromatography}

Fractions, with the highest enzymatic activity, obtained from the cationic exchange chromatography, were concentrated and loaded. A fraction with $19.25 \mathrm{mg}$ of protein with $4279 \mathrm{U}$ of enzymatic activity was eluded through a gel filtration column of $100 \mathrm{~cm}$ and length $\times 1.5 \mathrm{~cm}$ diameter, packed with Sephacryl S-200HR (Sigma-Aldrich, Saint Louis, MO, USA), equilibrated with PBS $200 \mathrm{mM} \mathrm{pH} 7.2$ with 
a flow of $10 \mathrm{~mL} / \mathrm{h}$, at room temperature. Fractions of $2.0 \mathrm{~mL}$ were collected, which were quantified protein and enzymatic activity.

\subsubsection{Anionic Exchange Chromatography}

4,102 U obtained from gel filtration with $5107 \mathrm{mg}$ of protein were eluted through a commercial $5 \mathrm{~cm}$ long $\times 1.5 \mathrm{~cm}$ in diameter Hi Trap Q Sepharose Fast Flow (QFF) anion exchange column (Sigma Chemical, Co., Saint Louis, MO, USA). This was previously equilibrated with $200 \mathrm{mM}$ PBS pH 7.2 with a flow of $30 \mathrm{~mL} / \mathrm{h}$ at room temperature, collecting $5.0 \mathrm{~mL}$ fractions. Protein and enzymatic activity were quantified.

\subsubsection{Dialysis and Lyophilization}

The fractions with the highest enzymatic activity obtained from anion exchange chromatography were dialyzed against triple distilled water at $4{ }^{\circ} \mathrm{C}$ with several changes for $48 \mathrm{~h}$ and lyophilized for $24 \mathrm{~h}$, using dialysis bags with pores of maximum diameters for proteins of 13,000 kDa (Sigma Chemical, Co.).

\subsection{Determination of Molecular Mass and Identification of Molecular Aggregates in SDS-PAGE}

Homogeneity, molecular mass, and identification of high molecular weight aggregates of $\beta$-glucosidase II purified from Sechium edule were evaluated in electrophoresis SDS-PAGE according to Laemmli [34].

\subsubsection{Native-PAGE Electrophoresis}

To identify the formation of molecular aggregates, native-PAGE electrophoresis was employed using $0.05 \mathrm{M}$ phosphate buffer $\mathrm{pH}$ 8.3, according to Hedricks and Smith [35], and Ferguson et al. [36].

\subsubsection{Acetate-Urea Acid Electrophoresis}

$\beta$-Glucosidase previously identified as a molecular complex was analyzed by denaturing acid electrophoresis in AU-PAGE using the method described by Reisfeld et al. [37]. In the running buffer, $1.56 \% \beta$-alanine and $4 \%$ glacial acetic acid $\mathrm{pH} 4.4$, were used, and pyronin was added as an electrophoretic mobility indicator. The enzyme migrated like a cation.

\subsubsection{Two-Dimensional Electrophoresis}

A 2D electrophoresis analysis of the purified enzyme was performed, following the methodology described by O'Farrell et al. [38]. In all cases, the gels were stained with $0.1 \%$ Coomassie brilliant blue G-250 (Sigma Chemical, Co).

\subsection{Determination of Partial Amino Acid Sequence Using Nano-LC-ESI-MS/MS}

The enzyme was previously reduced with dithiothreitol (DTT) (Sigma-Aldrich), alkylated with iodoacetamide (Sigma-Aldrich) and digested "in solution" with trypsin (Promega Sequencing Grade Modified Trypsin; Madison, WI, USA), in $50 \mathrm{mM}$ ammonium bicarbonate $\mathrm{pH}$ 8.2, and incubated for $18 \mathrm{~h}$ at $37^{\circ} \mathrm{C}$. The peptides produced by enzymatic cleavage were desalted with Zip Tip C18 (Millipore; Billerica, MA, USA) and applied in an liquid chromatography-mass spectrometry with a nano-electrospray ionization source system (Nano-LC-ESI-MS/MS) (Quadrupole/time of flight, Ultima API, Micromass, Manchester, UK) composed of an EASY-nLC II nanoflow pump (Thermo-Fisher Co.; San Jose, CA, USA) coupled to a LTQ-Orbitrap Velos mass spectrometer (Thermo-Fisher Co.).

Calibration was performed with a Calmix solution (N-butylamine, caffeine, Met-Arg-Phe-Ala peptide and Ultramark 1621). In order to calibrate the LTQ Velos with ion trap (IT) module and the Orbitrap module with FT (Fourier Transform) mass detector in ESI positive ionization mode. $\mathrm{N}$-Butylamine $(73.14 \mathrm{Da}$ ) is included to extend mass calibration to lower values of $\mathrm{m} / \mathrm{z}$ of 5 parts per million (ppm). 
In the nano-flow liquid chromatography, a gradient system of $10-80 \%$ solvent $B$ (water/acetonitrile with $0.1 \%$ formic acid) and solvent $A$ (water with $0.1 \%$ formic acid) was used for 120 min using a capillary column (ID $0.75 \mu \mathrm{m}$ and $10 \mathrm{~cm}$ length RP-C18). The flow of the LC system was 300 nanoliters/minute.

Total ion scanning (Full Scan) was performed on the Orbitrap analyzer with a resolution power of mass (RP Power; RP = m/FWHM) of 60,000 kDa. Peptide fragmentation was performed using the methods of Collision-Induced Dissociation (CID) and High-Energy Collision Dissociation (HCD). All spectra were acquired in positive detection mode. The execution and capture of the fragmentation data was performed depending on the total ion scan according to the pre-determined charges (only ions with a $z 2+, z 3+$ and $z 4+$ charge). These were fragmented with an isolation width of $2.0(\mathrm{~m} / \mathrm{z})$, normalized collision energy of 35 arbitrary units, Q activation of 0.250 , activation time of 10 milliseconds and maximum injection time of 10 milliseconds per micro-scan. During the automatic data capture, the dynamic ion exclusion was used: (i) 200 ion exclusion list, (ii) 30 seconds (s) pre-exclusion time, and (iii) 70 s exclusion time [39].

\subsection{Bioinformatic Analysis}

Spectrometric data was obtained in raw format in the Proteome Discoverer 1.4 program (Thermo-Fisher Co.) through the Sequest HT search engine. For the identity search, we used the database of all proteins organisms, Sechium, and $\beta$-glucosidase (UniProt). An FDR-False Discovery Rate of 0.01 (Minimum) and FDR of 0.05 (Maximum) was used in addition to the inverted database (Decoy database) as a tool of the "Percolator" validation program. The maximum tolerance of molecular mass difference of the precursor ion and the theoretical versus experimental values (precursor mass tolerance) were compared, it was $20 \mathrm{ppm}$ and the tolerance for the fragments obtained by dissociation of the precursor ion (fragment mass tolerance) of 0.6. For the automatic search, constant modifications (carbamide-methylation of cysteines) and variables such as oxidation of methionine (M) and deamination of asparagine $(\mathrm{N})$ and glutamine $(\mathrm{Q})$ were established.

After the automatic search, manual sequencing of the MS/MS spectra was performed. The sequences obtained are reported in Table 1 , with their ion $m / z, z^{+}$(charge), molecular mass (MW), and the sequence identity was obtained using BLAST [40].

\subsection{Enzymatic Activity}

Enzymatic activity of the crude extract and all purified fractions was measured using $p$ NPG as a substrate. The fractions were diluted (1:100) in $0.2 \mathrm{M}$ sodium citrate $\mathrm{pH}$ 5.0. $50 \mu \mathrm{L}$ of the sample was incubated with $50 \mu \mathrm{L}$ of the $5 \mathrm{mM}$ substrate at $25^{\circ} \mathrm{C}$ for $5 \mathrm{~min}$ in a 96 well microtiter plate. The reaction was stopped with $50 \mu \mathrm{L}$ of $400 \mathrm{mM}$ sodium bicarbonate $\left(\mathrm{NaHCO}_{3}\right)$. The $p \mathrm{NP}$ produced was quantified at $410 \mathrm{~nm}$, one unit of activity was defined as the amount of enzyme capable of catalyzing the hydrolysis of a $1 \mu \mathrm{M}$ of substrate per hour. Specific activity (SA) was expressed in units of enzyme per mg of protein $[29,33]$. Protein concentration was determined through the Bradford method [32].

\subsection{Determination of Kinetic Parameters}

$K_{m}, k_{c a t}$, and the $K_{m} / k_{\text {cat }}$ ratio were determined using $0-100 \mathrm{mM}$ of $p$-nitrophenyl$\beta$-D-glucopyranoside, $p$-nitrophenyl- $\beta$-D-galactopyranoside and $p$-nitrophenyl- $\beta$-D-fucopyranoside by each $4 \mu \mathrm{g}$ of $\beta$-glucosidase from Sechium edule in $0.2 \mathrm{M}$ sodium citrate buffer $\mathrm{pH} 5.0$, in $100 \mu \mathrm{L}$ reaction volume at $40{ }^{\circ} \mathrm{C}$ for $5 \mathrm{~min}$. The data obtained were analyzed using nonlinear regression with Prism 6 (GraphPad Software. Inc., San Diego, CA, USA).

Additionally, the following substrates were also evaluated to determine the specificity of $\beta$-glucosidase II using the same methodology: $p$-nitrophenyl- $\beta$-D-cellobioside, $p$-nitrophenyl- $\beta$-Dmannopyranoside, $p$-nitrophenyl- $\beta$-D-lactopyranoside, $p$-nitrophenyl- $\beta$-D-maltopyranoside, $p$-nitrophenyl- $\beta$-D- $N-N^{\prime}$-diacetylchitotriose, $p$-nitrophenyl- $\beta$-D- $N$-acetylgalactosamine, and $p$-nitrophenyl - $\alpha$-D-glucopyranoside. We only report $p$-nitrophenyl- $\beta$-D-glucopyranoside, $p$-nitrophenyl- $\beta$-Dgalactopyranoside, and $p$-nitrophenyl- $\beta$-D-fucopyranoside results. 


\section{Conclusions}

The process of purification of $\beta$-glucosidase from Sechium edule was adapted, incorporating other elements described and discussed above. We obtained a homogeneous purified preparation of the isoform II, which forms molecular complexes of high molecular weight, with aggregating properties. These complexes were not found in previous studies of isoform I [10]. We attribute this property to the content of non-polar amino acids that form hydrophobic, intra and intermolecular interactions. In contrast to $\beta$-glucosidase from Gramineae, which has previously been reported as responsible for the formation of molecular aggregates into the protein. $\beta$-Glucosidase aggregating factor, is not present in Sechium edule described here. The partial sequence of 179 amino acids corresponds to 35\% of the $\beta$-glucosidase sequence of cyanogenic $\beta$-glucosidase-like (Cucurbita moschata), a member of the Cucurbitaceae family. The sequence reported in the Fasta format of $\beta$-glucosidase II was analyzed by BLAST (https://blast.ncbi.nlm.nih.gov/Blast.cgi\#alnHdr_XP_022960706.1), obtaining an identity of 61\% with Cucurbita moschata with an e-value of 2e-59.

Two motif peptides TFNEP and ITENG, were identified as belonging to the catalytic site that contributes to the recognition of the substrate. This has a sequence similar to that reported in grasses and legumes which are identical to those reported in both Cucurbitaceae, and Gramineae. Their specificity was directed towards $\beta$-D-glucose $>\beta$-D-galactose $>\beta$-D-fucose and their kinetic parameters were similar between these substrates. The characteristics described in this work suggest the identity of $\beta$-glucosidase II as belonging to the GH1 family.

Author Contributions: M.M.C., E.P.-C., E.Z., M.d.S.P.-C. and M.T.H.-H. designed and supervised this research project. A.C.R., F.A.S.E., E.A.B.P., L.Á.S.P., A.J.D.B. and C.R.D. assisted in the research and performed the bioinformatic analysis. R.M.C., C.A.M.-C., L.P.-C.M., E.P.-C., E.P.-C.M., A.D.P.S., A.M.B., G.M.-A. and M.M.C. participated in the study writing the text, in the final version and critical revision of the manuscript. All authors have read and agreed to the published version of the manuscript.

Funding: This work was supported by the Tecnológico Nacional de México/Instituto Tecnológico de Oaxaca, research project number 5815.16-P, 5302.19-P, and Facultad de medicina, UNAM.

Acknowledgments: The authors thank Araceli Hernández Flores, Eli Cruz Parada and Charlotte Grundyfor theirs technical assistance, Carlos Solórzano for performing the electrophoretic analysis in her laboratory and Manuel Sánchez Rubio for the critical revision of the manuscript.

Conflicts of Interest: The authors declare no conflict of interest.

\section{References}

1. Walz, C.; Giavalisco, P.; Schad, M.; Juenger, M.; Klose, J.; Kehr, J. Proteomics of curcurbit phloem exudate reveals a network of defence proteins. Phytochemistry 2004, 65, 1795-1804. [CrossRef] [PubMed]

2. Malboobi, M.A.; Lefebvre, D.D. A phosphate-starvation inducible beta-glucosidase gene (psr3.2) isolated from Arabidopsis thaliana is a member of a distinct subfamily of the BGA family. Plant Mol. Biol. 1997, 34, 57-68. [CrossRef] [PubMed]

3. van de Ven, W.T.; LeVesque, C.S.; Perring, T.M.; Walling, L.L. Local and systemic changes in squash gene expression in response to silver winged whitefly feeding. Plant Cell 2000, 12, 1409-1423. [CrossRef] [PubMed]

4. Kawasaki, S.; Borchert, C.; Deyholos, M.; Wang, H.; Brazille, S.; Kawai, K.; Galbraith, D.; Bohnert, H.J. Gene expression profiles during the initial phase of salt stress in rice. Plant Cell 2001, 13, 889-905. [CrossRef]

5. Thorlby, G.; Fourier, N.; Warren, G. The SENSITIVE TO FREEZING2 gene, required for freezing tolerance in Arabidopsis thaliana, encodes a $\beta$-glucosidase. Plant Cell 2004, 16, 2192-2203. [CrossRef]

6. Lipka, V.; Dittgen, J.; Bednarek, P.; Bhat, R.; Wiermer, M.; Stein, M.; Landtag, J.; Brandt, W.; Rosahl, S.; Scheel, D.; et al. Pre- and postinvasion defenses both contribute to nonhost resistance in Arabidopsis. Science 2005, 310, 1180-1183. [CrossRef]

7. Li, Q.; Li, P.; Sun, L.; Wang, Y.; Ji, K.; Sun, Y.; Leng, P. Expression analysis of $\beta$-glucosidase genes that regulate abscisic acid homeostasis during watermelon (Citrullus lanatus) development and under stress conditions. J. Plant Physiol. 2012, 169, 78-85. [CrossRef]

8. Rachmawati, Y.; Aristya, G.R.; Daryono, B.S. CmBGI Gene Expression encoding $\beta$-glucosidase in melon (Cucumis melo L.) under stress condition. Biotropic J. Trop. Biol. 2017, 1, 1-8. [CrossRef] 
9. Hamissou, M.; Smith, A.C.; Carter Jr, R.E.; Triplett II, J.K. Antioxidative properties of bitter gourd (Momordica charantia) and zucchini (Cucurbita pepo). Emir. J. Food Agric. 2013, 25, 641-647. [CrossRef]

10. Espíndola-Mateos, S.; Cervantes, C.A.; Zenteno, E.; Slomianny, M.C.; Alpuche, J.; Hernández-Cruz, P.; Martínez-Cruz, R.; Pina-Canseco, M.S.; Pérez-Campos, E.; Rubio, M.S.; et al. Purification and partial characterization of $\beta$-Glucosidase in Chayote (Sechium edule). Molecules 2015, 20, 19372-19392. [CrossRef]

11. Poungbangpho, S.; Chuasuwan, S.; Chuphayak, C. Screening of $\beta$-D-galactosidase, $\beta$-D-glucosidase, and alpha-D-mannosidase in the seeds of cucurbitaceae. Naresuan Univ. 2000, 8, 56-67.

12. Henrissat, B. A classification of glycosyl hydrolases based on amino acid sequence similarities. Biochem. J. 1991, 280, 309-316. [CrossRef] [PubMed]

13. Henrissat, B.; Davies, G. Structural and sequence-based classification of glycosyl hydrolases. Curr. Opin. Struct. Biol. 1997, 7, 637-644. [CrossRef]

14. Rosales-Calderon, O.; Trajano, H.L.; Duff, S.J. Stability of commercial glucanase and $\beta$-glucosidase preparations under hydrolysis conditions. PeerJ 2014, 2, e402. [CrossRef] [PubMed]

15. Santos, J.C.S.D.; Barbosa, O.; Ortiz, C.; Berenguer-Murcia, A.; Rodrigues, R.C.; Fernandez-Lafuente, R. Importance of the support properties for immobilization or purification of enzymes. ChemCatChem 2015, 7, 2413-2432. [CrossRef]

16. Barbosa, O.; Ortiz, C.; Berenguer-Murcia, Á.; Torres, R.; Rodriguez, R.C.; Fernandez-Lafuente, R. Strategies for the one-step immobilization-purification of enzymes as industrial biocatalysts. Biotechnol. Adv. 2015, 33, 435-456. [CrossRef]

17. Castro-Rodríguez, J.M.; Toledo-Díaz, A.M.; Rodríguez-Galdón, B.; Perdomo-Molina, A.; Rodríguez-Rodríguez, E.M.; Díaz-Romero, C. Caracterización morfológica y composición química de chayotas (Sechium edule) cultivadas en las Islas Canarias (España). Arch. Latinoam. De Nutr. 2015, 65, 243-253. Available online: http://www.alanrevista.org/ediciones/2015/4/art-5/ (accessed on 15 November 2019).

18. Berg, J.M.; Tymoczko, J.L.; Stryer, L. Prelude: Biochemistry and the Genomic Revolution. In Biochemistry, 5th ed.; W.H. Freeman and Company: New York, NY, USA, 2002; pp. 14-15, ISBN-10: 0-7167-3051-0.

19. Vassão, D.G.; Wielsch, N.; Gomes, A.M.D.M.M.; Gebauer-Jung, S.; Hupfer, Y.; Svatoš, A.; Gershenzon, J. Plant defensive $\beta$-glucosidases resist digestion and sustain activity in the gut of a lepidopteran herbivore. Front. Plant Sci. 2018, 9, 1389. [CrossRef]

20. Yamada, K.; Hara-Nishimura, I.; Nishimura, M. Unique defense strategy by the endoplasmic reticulum body in plants. Plant Cell Physiol. 2011, 52, 2039-2049. [CrossRef]

21. Ketudat-Cairns, J.R.; Esen, A. $\beta$-Glucosidases. Cell Mol. Life Sci. 2010, 67, 3389-3405. [CrossRef]

22. Roy, A.; Kucukural, A.; Zhang, Y. I-TASSER: A unified platform for automated protein structure and function prediction. Nat. Protoc. 2010, 5, 725-738. [CrossRef] [PubMed]

23. Pettersen, E.F.; Goddard, T.D.; Huang, C.C.; Couch, G.S.; Greenblatt, D.M.; Meng, E.C.; Ferrin, T.E. UCSF Chimera-A Visualization System for Exploratory Research and Analysis. J. Comput. Chem. 2004, 25, 1605-1612. [CrossRef] [PubMed]

24. Cicek, M.; Esen, A. Expression of soluble and catalytically active plant (monocot) $\beta$-glucosidases in E. coli. Biotechnol. Bioeng. 1999, 63, 392-400. [CrossRef]

25. Cicek, M.; Esen, A. Structure and expression of a dhurrinase ( $\beta$-glucosidase) from sorghum. Plant Physiol. 1998, 116, 1469-1478. [CrossRef] [PubMed]

26. Gus-Mayer, S.; Brunner, H.; Schneider-Poetsch, H.A.; Rüdiger, W. Avenacosidase from oat: Purification, sequence analysis and biochemical characterization of a new member of the BGA family of $\beta$-glucosidases. Plant Mol. Biol. 1994, 26, 909-921. [CrossRef] [PubMed]

27. Opassiri, R.; Cairns, J.R.K.; Akiyama, T.; Wara-Aswapati, O.; Svasti, J.; Esen, A. Characterization of a rice $\beta$-glucosidase highly expressed in flower and germinating shoot. Plant Sci. 2003, 165, 627-638. [CrossRef]

28. Kittur, F.S.; Lalgondar, M.; Yu, H.Y.; Bevan, D.R.; Esen, A. Maize $\beta$-glucosidase-aggregating factor is a polyspecific jacalin-related chimeric lectin, and its lectin domain is responsible for $\beta$-glucosidase aggregation. J. Biol. Chem. 2007, 282, 7299-7311. [CrossRef]

29. Molina, J.; Landa, A.; Bautista, G.; Martínez, M.; Córdoba, F. Molecular association of lectin and $\beta$-glucosidase in corn coleoptile. Biochim. Et Biophys. Acta (Bba)-Gen. Subj. 2004, 1674, 299-304. [CrossRef]

30. Vozari-Hampe, M.M.; Viegas, C.; Saucedo, C.; Rosseto, S.; Manica, G.G.; Hampe, O.G. A lectin from Sechium edule fruit exudate. Phytochemistry 1992, 31, 1477-1480. [CrossRef] 
31. González-Lucas, J.; Báez-Santacruz, J.; Serna-Lagunes, R.; Llarena-Hernández, R.C.; Núñez-Pastrana, R.; Reynoso-Velasco, D. Phytophagous true bugs (Hemiptera: Heteroptera) associate with chayote crops (Sechium edule jacq) in central Veracruz México. Entomol. Agrícola 2019, 6, 170-176.

32. Bradford, M.M. A rapid and sensitive method for quantitation of micrograms quantities of proteins utilizing the principles of protein dye-binding. Anal. Biochemistry 1976, 72, 248-254. [CrossRef]

33. Esen, A. Purification and partial characterization of maize (Zea mays L.) $\beta$-glucosidase. Plant Physiol. 1992, 98, 174-182. [CrossRef] [PubMed]

34. Laemmli, U.K. Cleavage of structural proteins during the assembly of the head of bacteriophase T4. Nature 1970, 227, 680-685. [CrossRef] [PubMed]

35. Hedrick, J.L.; Smith, A.J. Size and charge isomer separation and estimation of molecular weights of proteins by disc gel electrophoresis. Arch. Biochem. Biophys. 1968, 126, 155-164. [CrossRef]

36. Ferguson, K.A. Starch-gel electrophoresis-application to the classification of pituitary proteins and polypeptides. Metabolism 1964, 13, 985-1002. [CrossRef]

37. Reisfeld, R.A.; Lewis, U.; Williams, D.E. Disk electrophoresis of basic proteins and peptides on polyacrylamide gels. Nature 1962, 195, 281-283. [CrossRef] [PubMed]

38. O'Farrell, P.H. High resolution two-dimensional electrophoresis of proteins. J. Biol. Chem. 1975, 250, 4007-4021.

39. Findlay, J.B.; Pappin, D.J.; Keen, J. Automated solid-phase microsequencing. In Protein Sequencing: A Practical Approach; Findlay, J.B., Geisow, M.J., Eds.; IRL Publishers: Oxford, UK, 1989; pp. 69-84. ISBN1 0199630135. ISBN2 9780199630134.

40. Zhang, D.M.; Feng, L.X.; Li, L.; Liu, M.; Jiang, B.H.; Yang, M.; Li, G.Q.; Wu, W.Y.; Guo, D.A.; Liu, X. Nano-LC-ESI MS/MS analysis of proteins in dried sea dragon Solenognathus hardwickii and bioinformatic analysis of its protein expression profiling. Chin. J. Nat. Med. 2016, 14, 709-713. [CrossRef]

Sample Availability: Samples of the $\beta$-Glucosidase from chayote (Sechium edule) are available from the authors.

(C) 2020 by the authors. Licensee MDPI, Basel, Switzerland. This article is an open access article distributed under the terms and conditions of the Creative Commons Attribution (CC BY) license (http://creativecommons.org/licenses/by/4.0/). 